\title{
Performance, metabolic, and endocrine responses of periparturient Holstein cows fed 3 sources of fat ${ }^{1}$
}

\author{
C. Caldari-Torres, ${ }^{\star}$ A. L. Lock, $†$ C. R. Staples, $\neq$ and L. Badinga $\neq^{2}$ \\ *Department of Dairy Science, Virginia Tech, Blacksburg 24061 \\ †Department of Animal Science, Michigan State University, East Lansing 48824 \\ ‡Department of Animal Sciences, University of Florida, Gainesville 32611
}

\begin{abstract}
The objective of this study was to examine the effect of feeding diets containing fat supplements enriched in either saturated fatty acids $(\mathrm{n}=10)$, Ca salts of transoctadecenoic fatty acids $(t \mathrm{FA}, \mathrm{n}=10)$ or Ca salts of safflower oil fatty acids (SFL, high in linoleic acid, $\mathrm{n}=$ 9) on performance, metabolic, and endocrine responses of periparturient Holstein cows. Dietary treatments were initiated at approximately $28 \mathrm{~d}$ before calculated calving dates and continued through $49 \mathrm{~d}$ postpartum. Blood samples for metabolite and hormone analyses were collected weekly beginning 1 wk before estimated calving date through 7 wk postpartum. Incorporation of $t \mathrm{FA}$ or SFL into the peripartum diet had no detectable effects on body weight or body condition score. Cows fed the SFL-enriched diet produced less milk fat and established a positive energy balance sooner after calving than those fed the $t \mathrm{FA}$ supplement. Analysis for individual fatty acids resulted in increased concentrations of trans 18:1 fatty acid and conjugated linoleic acid isomers in milk fat from cows supplemented with SFL. Across weeks, the average nonesterified fatty acids concentration in plasma was lower in cows fed the SFL-enriched diet than in those consuming the $t \mathrm{FA}$ supplemented diet. Mean concentrations of plasma glucose, insulin-like growth factor-I, and progesterone were greater in cows fed the SFL-enriched diet compared with those fed the saturated fatty acid-supplemented diet. Feeding fat supplements that can suppress milk fat production during the early postpartum period may help minimize negative energy balance, reduce adipose tissue mobilization, and improve circulating concentrations of insulin-like growth factor-I and progesterone. Whether the SFL supplement would have similar effects without a decrease in milk fat production remains to be determined and warrants further investigation.
\end{abstract} Key words: fat, performance, metabolite, cattle

\footnotetext{
Received August 20, 2010.

Accepted November 29, 2010.

${ }^{1}$ This manuscript is published as part of the Journal Series of the University of Florida Agriculture Experiment Station.

${ }^{2}$ Corresponding author: lbadinga@ufl.edu
}

\section{INTRODUCTION}

Concentration of plasma NEFA usually increases around calving due to mobilization of adipose tissue as a result of the inability of high-producing cows to consume enough energy to meet requirements for milk production and maintenance (Bell, 1995; Drackley, 1999). Elevated NEFA concentration in the periparturient period is the major factor influencing postpartum accumulation of lipid in hepatic tissue (Bell, 1981). When lipid accumulation in liver is excessive, cow performance can be decreased (Herdt, 1988). Therefore, management practices that minimize adipose tissue mobilization postpartum may be beneficial to cow performance. Whereas postpartum fat supplementation is a common practice in the dairy industry, prepartum fat supplementation is less common. Although most studies report an elevated concentration of plasma NEFA when fat is supplemented to the diet of lactating dairy cows (Grummer and Carroll, 1991), this response is not unequivocal. Grum et al. (1996) reported that feeding fat (6.5\% of dietary DM) to dairy cows during the nonlactating period essentially abolished accumulation of triacylglycerol in liver during the immediate postpartum period. Pregnant Holstein cows supplemented with fat at 0 or $4 \%$ of dietary DM during the 60 -d nonlactating period did not differ in plasma concentrations of NEFA either pre- or postpartum (Douglas et al., 2004). Plasma concentrations of NEFA were lower postpartum when Holstein cows were fed supplemental fat at 4 and $3.6 \%$ of dietary DM in ad libitum amounts from dry off to $15 \mathrm{~d}$ before calving and the last $14 \mathrm{~d}$ of pregnancy, respectively (Douglas et al., 2006). Similarly, Doepel et al. (2002) reported that Holstein cows fed higher energy diets that included tallow during the prepartum period had decreased plasma concentrations of NEFA on the day of calving but did not differ thereafter and had lower triglyceride concentrations in liver at 1 DIM. Importantly, the profile of fatty acid (FA) supplements may affect plasma concentrations of NEFA. Cows fed linseed oil (1.35\% of dietary DM prepartum and 1.5\% of dietary DM postpartum) had greater plasma concentrations of NEFA at 2 and 5 wk postpartum and greater hepatic concentrations of fat at 2 wk postpartum com- 
pared with cows fed a high linoleic acid fat formulated at the same FA concentrations (Amaral, 2008). These results collectively indicate that, in dairy cattle, the net effect of fat supplementation during the transition period on NEFA is not consistent.

Metabolic adaptations during the transition to lactation are coordinated by changes in plasma concentrations of key hormones and by tissue-specific variations in hormonal sensitivity and responsiveness (Bell, 1995; Bell and Bauman, 1997). Under normal physiological conditions, pituitary-derived growth hormone $(\mathbf{G H})$ increases systemic concentration of IGF-I, which, in turn, inhibits further GH production by the pituitary gland (Bichell et al., 1992; Le Roith et al., 2001). However, in situations of high nutrient demand, such as during the transition to lactation, the GH-IGF-I axis uncouples in the liver (Thissen et al., 1994), and this is associated with a decrease in total circulating IGF-I and elevated GH concentrations (Sharma et al., 1994; Vandehaar et al., 1995; Taylor et al., 2004). These observations suggest that the actions of GH vary considerably under different physiological states (Etherton and Bauman, 1998; Fenwick et al., 2008). Data on the effect of dietary FA on circulating IGF-I in dairy cattle are conflicting (Cullens et al., 2004; Bilby et al., 2006), and the mechanism by which supplemental fats affect periparturient endocrine events warrants further investigation.

Currently, data are limited that relate periparturient fat supplementation and peripheral concentrations of homeostatic hormones in dairy cows. Because commonly-fed fat sources vary in FA profiles, we hypothesized that diets enriched in saturated, transmonounsaturated, or omega-6 FA may have distinct effects on performance and plasma metabolites related to energy metabolism in early lactating dairy cows. The objective of this study was to examine the effect of feeding diets containing fat supplements enriched in either saturated fatty acids (SFA), Ca salts of transoctadecenoic fatty acids ( $\boldsymbol{t} \mathbf{F A})$, or Ca salts of safflower oil fatty acids (SFL) on performance, metabolic, and endocrine responses of periparturient Holstein cows.

\section{MATERIALS AND METHODS}

\section{Experimental Animals and Diets}

Twenty-nine multiparous Holstein cows were used in a completely randomized design to determine the effect of feeding diets enriched in SFA (RBF, Cargill, Minneapolis, MN; approximately $90 \% \mathrm{SFA} ; 1.5 \%$ of DM; $\mathrm{n}=10$ ), $t \mathrm{FA}$ (Energ-TR, Virtus Nutrition, Fairlawn, $\mathrm{OH}$; approximately $61 \%$ trans-18:1 isomers; $1.8 \%$ of DM; $\mathrm{n}=10$ ), or SFL (Prequel-21, Virtus Nutrition;
Table 1. Fatty acid profile (\% weight) of saturated fatty acids (SFA), Ca salts of trans-octadecenoic acids ( $t \mathrm{FA})$, and Ca salts of safflower oil (SFL)

\begin{tabular}{lccc}
\hline & \multicolumn{3}{c}{ Fat supplement } \\
\cline { 2 - 4 } Fatty acid & SFA $^{1}$ & $t$ FA $^{2}$ & SFL $^{3}$ \\
\hline C14:0 & 5.60 & 0.31 & 1.00 \\
C16:0 & 37.80 & 12.21 & 12.90 \\
C16: 1 & - & 0.15 & 0.13 \\
C18:0 0 trans-6-8 & 48.00 & 6.70 & 4.20 \\
C18:1 trans-9 & - & 20.62 & - \\
C18:1 trans-10 & - & 10.47 & - \\
C18:1 trans-11 & - & 10.62 & - \\
C18:1 trans-12 & - & 7.05 & - \\
C18:2 & - & 8.73 & - \\
C18:3 9 & 4.80 & 10.04 & 16.70 \\
Others & - & 1.97 & 63.60 \\
\hline
\end{tabular}

${ }^{1}$ Fatty acid composition provided by Cargill (RBF; Cargill, Minneapolis, $\mathrm{MN}$ ).

${ }^{2}$ Fatty acid composition provided by Virtus Nutrition (EnerG-TR; Virtus Nutrition, Fairlawn, OH).

${ }^{3}$ Fatty acid composition provided by Virtus Nutrition (Prequel-21; Virtus Nutrition).

approximately $63 \%$ linoleic acid; $1.8 \%$ of $\mathrm{DM} ; \mathrm{n}=9$ ) on performance, metabolic, and endocrine responses of dairy cows during the transition to lactation. The FA profile of each fat supplement is summarized in Table 1. The experiment was conducted at the University of Florida Dairy Unit (Hague, FL) during the months of February through August, 2008. All animals were managed and experimental manipulations performed following the guidelines approved by the University of Florida Institute of Food and Agricultural Sciences Animal Research Committee.

Dietary treatments were initiated at approximately 28 $\mathrm{d}$ before calculated calving dates and continued through $49 \mathrm{~d}$ postpartum. Diets were isolipidic and formulated for intakes of approximately 150 to $200 \mathrm{~g} / \mathrm{d}$ prepartum and 250 to $300 \mathrm{~g} / \mathrm{d}$ postpartum of supplemental lipids. Fat supplements were mixed with the concentrates and offered as part of TMR to experimental animals.

Prepartum cows were managed in sod-based pens equipped with fans and sprinklers. Postpartum cows were housed in a freestall, sand-based barn equipped with fans and sprinklers. Pre- and postpartum intakes of DM were measured daily using a Calan gate system (American Calan Inc., Northwood, NH). All experimental animals were offered ad libitum amounts of TMR to allow for 5 to $10 \%$ refusals. Corn silage was the major forage component and ground corn was the primary concentrate. Dry matter of corn silage was determined weekly and the rations were adjusted accordingly to maintain constant forage:concentrate ratio on a DM 
Table 2. Ingredient composition ( $\%$ of DM) of prepartum and postpartum diets

\begin{tabular}{|c|c|c|}
\hline Ingredient & Prepartum & Postpartum \\
\hline Corn silage & 30 & 38 \\
\hline Bermudagrass silage & 35 & - \\
\hline Alfalfa hay & - & 12 \\
\hline Ground corn & 11.1 & 19.7 \\
\hline Citrus pulp & 9.3 & 5.2 \\
\hline Fat supplement ${ }^{1}$ & 1.5 to 1.8 & 1.5 to 1.8 \\
\hline Corn gluten feed & - & 5 \\
\hline Soybean meal & 6.7 & 7.5 \\
\hline SoyPlus $^{2}$ & - & 7 \\
\hline Mineral and vitamin $\operatorname{mix}^{3}$ & 6 & \\
\hline Mineral and vitamin $\operatorname{mix}^{4}$ & - & 3.8 \\
\hline Trace mineralized salt ${ }^{5}$ & 0.1 & - \\
\hline
\end{tabular}

${ }^{1}$ Fat sources were $1.5 \%$ saturated fatty acids (RBF; Cargill, Minneapolis, MN), 1.8\% Ca salts of fatty acids enriched in trans C18:1 isomers (EnerG-TR; Virtus Nutrition, Fairlawn, OH), and 1.8\% Ca salts of fatty acids enriched in safflower oil fatty acids (Prequel-21; Virtus Nutrition).

${ }^{2}$ West Central Soy, Ralston IA.

${ }^{3}$ Prepartum mineral and vitamin mix contained $24.0 \%$ of CP, $22.9 \%$ of Ca, $0.20 \%$ of $\mathrm{P}, 0.20 \%$ of $\mathrm{K}, 2.8 \%$ of $\mathrm{Mg}, 0.7 \%$ of $\mathrm{Na}, 2.4 \%$ of $\mathrm{S}, 8.0 \%$ of $\mathrm{Cl}, 147 \mathrm{mg}$ of $\mathrm{Mn} / \mathrm{kg}, 27 \mathrm{mg}$ of $\mathrm{Fe} / \mathrm{kg}, 112 \mathrm{mg}$ of $\mathrm{Cu} / \mathrm{kg}, 95 \mathrm{mg}$ of Se/ $\mathrm{kg}, 8 \mathrm{mg}$ of I/ $\mathrm{kg}, 11 \mathrm{mg}$ of $\mathrm{Co} / \mathrm{kg}, 268,130 \mathrm{IU}$ of vitamin A/ $\mathrm{kg}, 40,000$ IU of vitamin $\mathrm{D} / \mathrm{kg}$, and $1,129 \mathrm{IU}$ of vitamin $\mathrm{E} / \mathrm{kg}$ (DM basis).

${ }^{4}$ Postpartum mineral and vitamin mix contained $9.5 \%$ of $\mathrm{Ca}, 1.0 \%$ of $\mathrm{P}, 5.0 \%$ of $\mathrm{K}, 43.0 \%$ of $\mathrm{Mg}, 11.5 \%$ of $\mathrm{Na}, 1.1 \%$ of S, $2.0 \%$ of $\mathrm{Cl}, 1,200$ $\mathrm{mg}$ of $\mathrm{Mn} / \mathrm{kg}, 500 \mathrm{mg}$ of $\mathrm{Cu} / \mathrm{kg}, 1,500 \mathrm{mg}$ of $\mathrm{Zn} / \mathrm{kg}, 8.25 \mathrm{mg}$ of Se $/ \mathrm{kg}$, $20 \mathrm{mg}$ of I/ $\mathrm{kg}, 25 \mathrm{mg}$ of $\mathrm{Co} / \mathrm{kg}, 165,000 \mathrm{IU}$ of vitamin $\mathrm{A} / \mathrm{kg}, 880 \mathrm{IU}$ of vitamin $\mathrm{E} / \mathrm{kg}, 46,200 \mathrm{IU}$ of vitamin $\mathrm{D}_{3} / \mathrm{kg}$, and $300 \mathrm{~g} / \mathrm{t}$ Rumensin (Elanco, Greenfield, IN; DM basis).

${ }^{5}$ Trace mineralized salt contained minimum concentrations of $40 \%$ of $\mathrm{Na}, 55 \%$ of $\mathrm{Cl}, 2,500 \mathrm{mg}$ of $\mathrm{Mn} / \mathrm{kg}, 2,000 \mathrm{mg}$ of $\mathrm{Fe} / \mathrm{kg}, 330 \mathrm{mg}$ of $\mathrm{Cu} /$ $\mathrm{kg}, 70 \mathrm{mg}$ of I/ kg, $50 \mathrm{mg}$ of $\mathrm{Zn} / \mathrm{kg}$, and $25 \mathrm{mg}$ of Co/ $\mathrm{kg}$ (DM basis).

basis. Samples of forage and concentrate mixes were collected weekly, composited monthly, and analyzed by wet chemistry for fat (acid hydrolysis), $\mathrm{CP}, \mathrm{NDF}, \mathrm{ADF}$, and minerals (Dairy One, Ithaca NY). Ingredient and chemical compositions of experimental diets are listed in Tables 2 and 3, respectively.

Lactating cows were milked twice daily and milk weights recorded at each milking. For each cow, samples of milk from consecutive morning $(0700 \mathrm{~h})$ and evening $(1900 \mathrm{~h})$ milkings were collected on the same day during each week and analyzed for fat, protein, and SCC by Southeast Milk Laboratory (Belleview, FL) using a Bentley 2000 NIR analyzer (Bentley Instruments, Chaska, MN). Daily concentrations of fat and protein were calculated after adjusting for milk weight during those 2 milkings. Body weights were measured and BCS assigned weekly by the same individual.

Aliquots of milk collected at wk 6 and 7 were stored without preservative at $-20^{\circ} \mathrm{C}$ until analyzed for FA composition. Milk lipids were extracted using the method of Hara and Radin (1978), and FA methyl esters (FAME) prepared by base-catalyzed transmethylation (Christie, 1989). The FAME were quantified using a GC-2010 Plus gas chromatograph (Shimadzu, Kyoto, Japan) equipped with a split injector (1:100 split ratio) and a flameionization detector using a CP-Sil 88 WCOT fused silica column $(100 \mathrm{~m} \times 0.25$ - $\mathrm{mm}$ i.d. $\times 0.2-\mu \mathrm{m}$ film thickness; Varian Inc., Lake Forest, CA). Gas chromatographic conditions were described by Kramer et al. (2001). The FAME were identified by comparison of retention times with known FAME standards [Supelco 37 component FAME mix, cis/trans FAME mix, bacterial acid methyl ester (BAME) mix, and polyunsaturated FA (PUFA) No. 3 mix from Supelco Inc., Bellefonte, PA; GLC reference standard 463 and conjugated linoleic acid (CLA) mixture \#UC-59 M from Nu-Chek Prep, Elysian, MN]. Short-chain FAME were corrected for mass discrepancy using the correction factors published by Ulberth and Schrammel (1995).

\section{Blood Collection and Analysis}

Metabolite and hormone analyses were performed on blood samples collected at wk -1, 1, 2, 3, 4, 5, 6, and 7 relative to the day of parturition. For progesterone measurements, blood samples were collected 3 times per week from d 12 through 49 postpartum. Blood (approximately $20 \mathrm{~mL}$ ) was collected from coccygeal vessels into evacuated heparinized tubes (Vacutainer, Becton Dickinson, Franklin Lakes, NJ). Samples were placed immediately on ice and plasma harvested by centrifugation at $2,500 \times g$ at $4^{\circ} \mathrm{C}$ for $30 \mathrm{~min}$. Plasma was stored at $-20^{\circ} \mathrm{C}$ for subsequent metabolite and hormone analyses.

Concentrations of NEFA and glucose in plasma were measured enzymatically with commercial kits (Waco Chemicals USA Inc., Richmond, VA). Intra- and interassay coefficients of variation were 2.0 and $5.2 \%$ and 1.2 and $1.9 \%$ for NEFA and glucose, respectively. Least detectable concentrations were $50 \mu \mathrm{Eq} / \mathrm{L}$ and $25 \mathrm{mg} /$ dL for NEFA and glucose, respectively. Plasma insulin (Selberg et al., 2004) and IGF-I (Selberg et al., 2005) were measured using previously validated radioimmunoassay procedures. Least detectable concentrations were $0.3 \mathrm{ng} / \mathrm{mL}$ and $50 \mathrm{pg} / \mathrm{mL}$ for insulin and IGF-I assays, respectively. Intra- and interassay coefficients of variation were 9.1 and $14.9 \%$ for insulin and 11.4 and $12.1 \%$ for IGF-I, respectively. Plasma progesterone concentrations were determined using Coat-A-Count solid phase radioimmunoassay (DPC Diagnostic Products Inc., Los Angeles, CA). The sensitivity of the assay was $0.1 \mathrm{ng} / \mathrm{mL}$ and intra- and interassay coefficients of variation were 0.8 and $5.2 \%$, respectively. The first day of ovulation after parturition was determined by plasma progesterone concentrations $>1 \mathrm{ng} / \mathrm{mL}$ for 2 sampling days. 
Table 3. Chemical composition of prepartum and postpartum diets

\begin{tabular}{|c|c|c|c|c|c|c|}
\hline \multirow[b]{2}{*}{ Ingredient } & \multicolumn{3}{|c|}{ Prepartum diet } & \multicolumn{3}{|c|}{ Postpartum diet } \\
\hline & $\mathrm{SFA}^{1}$ & $t \mathrm{FA}^{2}$ & $\mathrm{SFL}^{3}$ & $\mathrm{SFA}^{1}$ & $t \mathrm{FA}^{2}$ & $\mathrm{SFL}^{3}$ \\
\hline $\mathrm{DM}(\%)$ & 45 & 45 & 45 & 56 & 56 & 56 \\
\hline $\mathrm{CP}(\%$ of $\mathrm{DM})$ & 14.2 & 14.4 & 14.5 & 17.8 & 17.4 & 17.6 \\
\hline $\mathrm{NDF}(\%$ of DM) & 43 & 41.8 & 42.7 & 27.9 & 27.9 & 28.2 \\
\hline $\mathrm{ADF}(\%$ of $\mathrm{DM})$ & 26 & 25.1 & 25.4 & 17.4 & 16.7 & 16.6 \\
\hline Lignin ( $\%$ of DM) & 4 & 3.9 & 4 & 3.1 & 3.2 & 3 \\
\hline NFC ( $\%$ of DM) & 30.6 & 31.9 & 31 & 44 & 45 & 45 \\
\hline Lipid (\% of DM) & 3.7 & 4.5 & 4.5 & 4.7 & 5.4 & 5.1 \\
\hline Ash (\% of DM) & 11.5 & 11.9 & 12 & 6.9 & 7.4 & 7.4 \\
\hline $\mathrm{NE}_{\mathrm{t}}{ }^{4}(\mathrm{Mcal} / \mathrm{kg})$ & 1.57 & 1.58 & 1.58 & 1.71 & 1.71 & 1.71 \\
\hline $\mathrm{Ca}$ (\% of DM) & 1.9 & 2.16 & 2.12 & 0.85 & 1.1 & 1.1 \\
\hline $\mathrm{P}(\%$ of $\mathrm{DM})$ & 0.3 & 0.32 & 0.3 & 0.4 & 0.4 & 0.4 \\
\hline $\mathrm{Mg}(\%$ of $\mathrm{DM})$ & 0.4 & 0.42 & 0.4 & 0.37 & 0.3 & 0.38 \\
\hline $\mathrm{K}(\%$ of $\mathrm{DM})$ & 1.83 & 1.82 & 1.82 & 1.35 & 1.28 & 1.32 \\
\hline $\mathrm{Na}(\%$ of $\mathrm{DM})$ & 0.2 & 0.2 & 1.82 & 0.35 & 0.38 & 0.4 \\
\hline $\mathrm{S}(\%$ of $\mathrm{DM})$ & 0.33 & 0.32 & 0.38 & 0.2 & 0.23 & 0.2 \\
\hline $\mathrm{Cl}(\%$ of $\mathrm{DM})$ & 1.08 & 1.1 & 1.1 & - & - & - \\
\hline $\mathrm{Fe}(\mathrm{mg} / \mathrm{kg})$ & 239 & 243 & 270 & 180 & 168 & 163 \\
\hline $\mathrm{Zn}(\mathrm{mg} / \mathrm{kg})$ & 41 & 45 & 43 & 76 & 77 & 61 \\
\hline $\mathrm{Cu}(\mathrm{mg} / \mathrm{kg})$ & 23 & 21 & 23 & 28 & 33 & 25 \\
\hline $\mathrm{Mn}(\mathrm{mg} / \mathrm{kg})$ & 38 & 37 & 40 & 78 & 80 & 76 \\
\hline Mo (mg/kg) & 1.4 & 1.2 & 1.1 & 1.6 & 1.3 & 1.4 \\
\hline
\end{tabular}

${ }^{1}$ Saturated fatty acids (RBF, Cargill Minneapolis, MN).

${ }^{2}$ Calcium salts of trans-octadecenoic fatty acids (EnerG-TR; Virtus Nutrition, Fairlawn, OH).

${ }^{3}$ Calcium salts of safflower oil fatty acids (Prequel-21; Virtus Nutrition).

${ }^{4}$ Calculated using NRC (2001) software.

\section{Statistical Analyses}

Performance, metabolic, and hormonal responses were condensed to weekly means and analyzed using the MIXED procedure of SAS (SAS Institute Inc., Cary, $\mathrm{NC})$. Fixed effects included dietary treatment, week relative to calving, and treatment $\times$ week interaction. The variance for cow nested within treatment was used as the random error term to test the main effect of treatment. Differential temporal responses to dietary treatments were further examined using the SLICE option of the MIXED procedure. In the absence of treatment $\times$ week interaction, main dietary effects were separated by preplanned orthogonal contrasts $(1=\mathrm{SFA}$ vs. $t \mathrm{FA}+$ SFL; and $2=t$ FA vs. SFL) and piecewise differentiable (PDIFF) category. Milk samples were composited for wk 6 and 7 and milk FA concentrations analyzed using the GLM procedure of SAS. Effects of diets on the number of days to first ovulation were analyzed using the LIFETEST procedure of SAS. Dietary treatments were considered as strata. Effects of dietary treatments on accumulated progesterone concentration were evaluated by regression analysis using the GLM procedure of SAS. Differences were considered to be significant at $P$ $<0.05$, whereas tendencies were discussed at $P>0.05$ but $<0.10$. Data are presented as least squares means \pm standard error of the means.

\section{RESULTS}

\section{Performance of Periparturient Holstein Cows Fed 3 Sources of Fat}

Fat feeding had no detectable effects on mean DMI, BW, BCS, or energy balance of prepartum cows (Table 4 and Figure 1). However, lactating cows supplemented with $t \mathrm{FA}(3.0 \%$ of $\mathrm{BW})$ consumed less feed than those receiving the SFA (3.5\% of BW) supplement (Table 4 and Figure 1). Mean postpartum DMI did not differ between $t \mathrm{FA}$ (3.0\% of BW) and SFL (3.3\% of BW) treatment groups (Table 4 and Figure 1). Both milk fat content and yield were lower for SFL-supplemented cows compared with the other treatments $(2.84 \%<$ 3.58 or $3.86 \%$; $0.95 \mathrm{~kg}<1.29$ or $1.30 \mathrm{~kg} / \mathrm{d}$; Table 5 ). As a result, FCM production was less in the SFL treatment group than the SFA group $(30.1 \mathrm{~kg}<37.4$ $\mathrm{kg})$. Neither milk protein nor SCC were affected by fat treatments (Table $5 ; P>0.05$ ). Postpartum energy balance was more positive $(P<0.05)$ in SFL-fed cows than in those receiving the $t \mathrm{FA}$-enriched diet (Table 4 and Figure 1). Analysis for individual FA revealed decreased concentrations of $\mathrm{C} 6: 0, \mathrm{C} 8: 0$, and $\mathrm{C} 18: 0$, but increased concentrations of trans C18:1 FA isomers, C18:2, C18:3, cis-9, trans-11 CLA, and trans-10, cis-12 CLA in milk fat from cows supplemented with SFL (Table 6). Concentrations of C18:1 trans-10 and 11 
Table 4. Dry matter intakes and changes in BW, BCS, and energy balance (EB) of peripartum Holstein cows fed diets containing fat supplements enriched in either saturated fatty acids (SFA), Ca salts of transoctadecenoic fatty acids ( $t \mathrm{FA})$, or Ca salts of safflower oil (SFL) fatty acids

\begin{tabular}{|c|c|c|c|c|c|c|}
\hline \multirow[b]{2}{*}{ Item } & \multicolumn{3}{|c|}{ Diet } & \multirow[b]{2}{*}{ SEM } & \multicolumn{2}{|c|}{$P$-value ${ }^{1}$} \\
\hline & $\begin{array}{c}\text { SFA } \\
(\mathrm{n}=10)\end{array}$ & $\begin{array}{c}t \mathrm{FA} \\
(\mathrm{n}=10)\end{array}$ & $\begin{array}{c}\text { SFL } \\
(\mathrm{n}=9)\end{array}$ & & $\mathrm{C} 1$ & $\mathrm{C} 2$ \\
\hline \multicolumn{7}{|c|}{ DMI (\% of BW) } \\
\hline Prepartum ${ }^{2}$ & 1.7 & 1.6 & 1.6 & 0.1 & 0.37 & 0.85 \\
\hline Postpartum $^{3}$ & $3.5^{\mathrm{a}}$ & $3.0^{\mathrm{b}}$ & $3.3^{\mathrm{ab}}$ & 0.2 & 0.16 & 0.21 \\
\hline \multicolumn{7}{|l|}{ BW (kg) } \\
\hline Prepartum & 738 & 762 & 708 & 26.4 & 0.9 & 0.15 \\
\hline Postpartum & 640 & 660 & 633 & 24.1 & 0.83 & 0.45 \\
\hline \multicolumn{7}{|l|}{$\mathrm{BCS}$} \\
\hline Prepartum & 3.47 & 3.47 & 3.41 & 0.09 & 0.75 & 0.66 \\
\hline Postpartum & 3.24 & 3.16 & 3.16 & 0.08 & 0.41 & 0.98 \\
\hline \multicolumn{7}{|l|}{$\mathrm{EB}(\mathrm{Mcal} / \mathrm{d})$} \\
\hline Prepartum & 4.6 & 3.6 & 2.8 & 1.3 & 0.37 & 0.66 \\
\hline Postpartum $^{5}$ & $2.1^{\mathrm{ab}}$ & $-0.1^{\mathrm{a}}$ & $4.7^{\mathrm{b}}$ & 1.6 & 0.93 & 0.05 \\
\hline
\end{tabular}

${ }^{a, b}$ Within the same row, means with different superscripts are statistically different, as determined by piecewise differentiable (PDIFF) category.

${ }^{1} \mathrm{C} 1=\mathrm{SFA}$ vs. $t \mathrm{FA}+\mathrm{SFL} ; \mathrm{C} 2=t \mathrm{FA}$ vs. SFL.

${ }^{2}$ Prepartum means were averaged over 4 wk before calving.

${ }^{3}$ Postpartum means were averaged over $7 \mathrm{wk}$ of lactation.

${ }^{4} \mathrm{~EB}=$ net energy intake - net energy for maintenance - net energy for pregnancy $=(\mathrm{DMI} \times 1.57 \mathrm{Mcal} / \mathrm{kg}$ of $\mathrm{DM})-($ metabolic BW $\times 0.08 \mathrm{Mcal} / \mathrm{kg}$ of metabolic BW $)-[(0.00318 \times$ days pregnant -0.0352$) \times$ calf birth weight] $/ 0.218$, according to NRC (2001).

${ }^{5} \mathrm{~EB}=$ net energy intake - net energy for maintenance - net energy for lactation $=(\mathrm{DMI} \times 1.71 \mathrm{Mcal} / \mathrm{kg}$ of $\mathrm{DM})-($ metabolic BW $\times 0.08 \mathrm{Mcal} / \mathrm{kg}$ of metabolic BW $)-[$ milk yield $\times(0.0929 \times \%$ milk fat $)+(0.0547 \times$ $\%$ milk true protein/0.93) +0.192$]$, according to NRC (2001).

were especially increased. Milk fat from cows fed the $t \mathrm{FA}$ supplement had lower concentrations of $\mathrm{C} 10: 0$ and C16:0 but greater concentrations of trans-4,5, 6-8,9, and 12 isomers of $\mathrm{C} 18: 1$ and cis-9, trans-11 CLA than did cows fed the SFA supplement (Table 6). Concentrations of trans-10 and 12 isomers of C18:1 were not different between cows fed SFA and $t$ FA.

\section{Metabolic Responses of Periparturient Holstein Cows Fed 3 Sources of Fat}

Mean concentration of plasma NEFA increased $(P<$ 0.01 ) from $295 \pm 72$ to $927 \pm 66 \mu \mathrm{Eq} / \mathrm{L}$ between wk -1 and +1 relative to parturition, and almost returned to pre-calving concentrations by wk 6 postpartum (Figure $2 \mathrm{~A})$. Overall plasma NEFA concentrations were lower $(P=0.05)$ in periparturient cows fed the SFL-enriched $\operatorname{diet}(483 \pm 64 \mu \mathrm{Eq} / \mathrm{L})$ than in cows fed the $t \mathrm{FA}$ supplement $(661 \pm 57 \mu \mathrm{Eq} / \mathrm{L})$ but did not differ from that of cows fed SFA $(626 \pm 59 \mu \mathrm{Eq} / \mathrm{L})$. Mean concentrations of plasma NEFA of cows fed $t \mathrm{FA}$ or SFA supplement did not differ $(P=0.12)$. Across all treatments, mean plasma glucose concentration decreased $(P<0.01)$ from $58.8 \pm 2.5$ to $47.1 \pm 2.3 \mathrm{ng} / 100 \mathrm{~mL}$ between wk -1 and +1 relative to parturition, and gradually increased thereafter (Figure 2B). Irrespective of the week relative to parturition, plasma glucose concentrations were greater in Holstein cows fed the SFL supplement than those fed the SFA supplement $(57.8 \mathrm{ng} / 100 \mathrm{~mL}$ $>46.8 \mathrm{ng} / 100 \mathrm{~mL}, P<0.01$; Figure $2 \mathrm{~B}$ ).

Mean insulin concentrations in plasma varied $(P<$ 0.01 ) among weeks relative to parturition, but did not differ among dietary treatments $(0.67,0.73$, and 0.73 $\mathrm{ng} / \mathrm{mL}$ for cows fed SFA, $t \mathrm{FA}$, and SFL, respectively; Figure 3A). Across all weeks, plasma insulin concentrations of cows fed SFL were greater numerically than those of cows fed SFA. Across all treatment groups, plasma IGF-I concentration decreased $(P<0.01)$ from $130.8 \pm 11.0$ to $64.9 \pm 10.1 \mathrm{ng} / \mathrm{mL}$ between wk -1 and +1 relative to parturition, and then progressively increased $(P<0.01)$ for the remainder of the study (Figure 3B). Pre- and postpartum plasma IGF-I concentrations were greater $(P<0.01)$ in Holstein cows supplemented with $t \mathrm{FA}(104.1 \mathrm{ng} / \mathrm{mL})$ or SFL (125.1 $\mathrm{ng} / \mathrm{mL}$ ) supplements compared with cows fed the SFAenriched diet (66.6 ng/mL; Figure 3B).

\section{Ovulation and Accumulated Progesterone Concentrations}

Although mean interval from calving to first ovulation did not differ among diets (mean number of days 
Table 5. Milk production and composition (average of $7 \mathrm{wk}$ ) of Holstein cows fed diets containing fat supplements enriched in either saturated fatty acids (SFA), Ca salts of trans-octadecenoic fatty acids $(t \mathrm{FA})$, or Ca salts of safflower oil (SFL) fatty acids

\begin{tabular}{|c|c|c|c|c|c|c|}
\hline \multirow[b]{2}{*}{ Variable } & \multicolumn{3}{|c|}{ Diet } & \multirow[b]{2}{*}{ SEM } & \multicolumn{2}{|c|}{$P$-value ${ }^{1}$} \\
\hline & SFA & $t \mathrm{FA}$ & SFL & & $\mathrm{C} 1$ & $\mathrm{C} 2$ \\
\hline Milk (kg/d) & 37.6 & 34.9 & 34.1 & 1.9 & 0.18 & 0.79 \\
\hline FCM $3.5 \%(\mathrm{~kg} / \mathrm{d})$ & $37.4^{\mathrm{a}}$ & $36.4^{\mathrm{ab}}$ & $30.1^{\mathrm{b}}$ & 2.2 & 0.13 & 0.06 \\
\hline Milk fat $(\%)$ & $3.58^{\mathrm{a}}$ & $3.86^{\mathrm{a}}$ & $2.84^{\mathrm{b}}$ & 0.16 & 0.25 & $<0.01$ \\
\hline Milk fat $(\mathrm{kg} / \mathrm{d})$ & $1.29^{\mathrm{a}}$ & $1.30^{\mathrm{a}}$ & $0.95^{\mathrm{b}}$ & 0.09 & 0.13 & 0.01 \\
\hline Milk protein (\%) & 2.86 & 2.75 & 2.92 & 0.07 & 0.81 & 0.11 \\
\hline Milk protein $(\mathrm{kg} / \mathrm{d})$ & 1.04 & 0.93 & 0.96 & 0.05 & 0.13 & 0.68 \\
\hline $\mathrm{SCC}^{2}$ & 130 & 206 & 131 & 79 & 0.69 & 0.52 \\
\hline
\end{tabular}

${ }^{a, b}$ Within the same row, means with different superscripts are statistically different, as determined by piecewise differentiable (PDIFF) category.

${ }^{1} \mathrm{C} 1=\mathrm{SFA}$ vs. $t \mathrm{FA}+\mathrm{SFL} ; \mathrm{C} 2=t \mathrm{FA}$ vs. SFL.

${ }^{2}$ Somatic cell count $\times 1,000$.
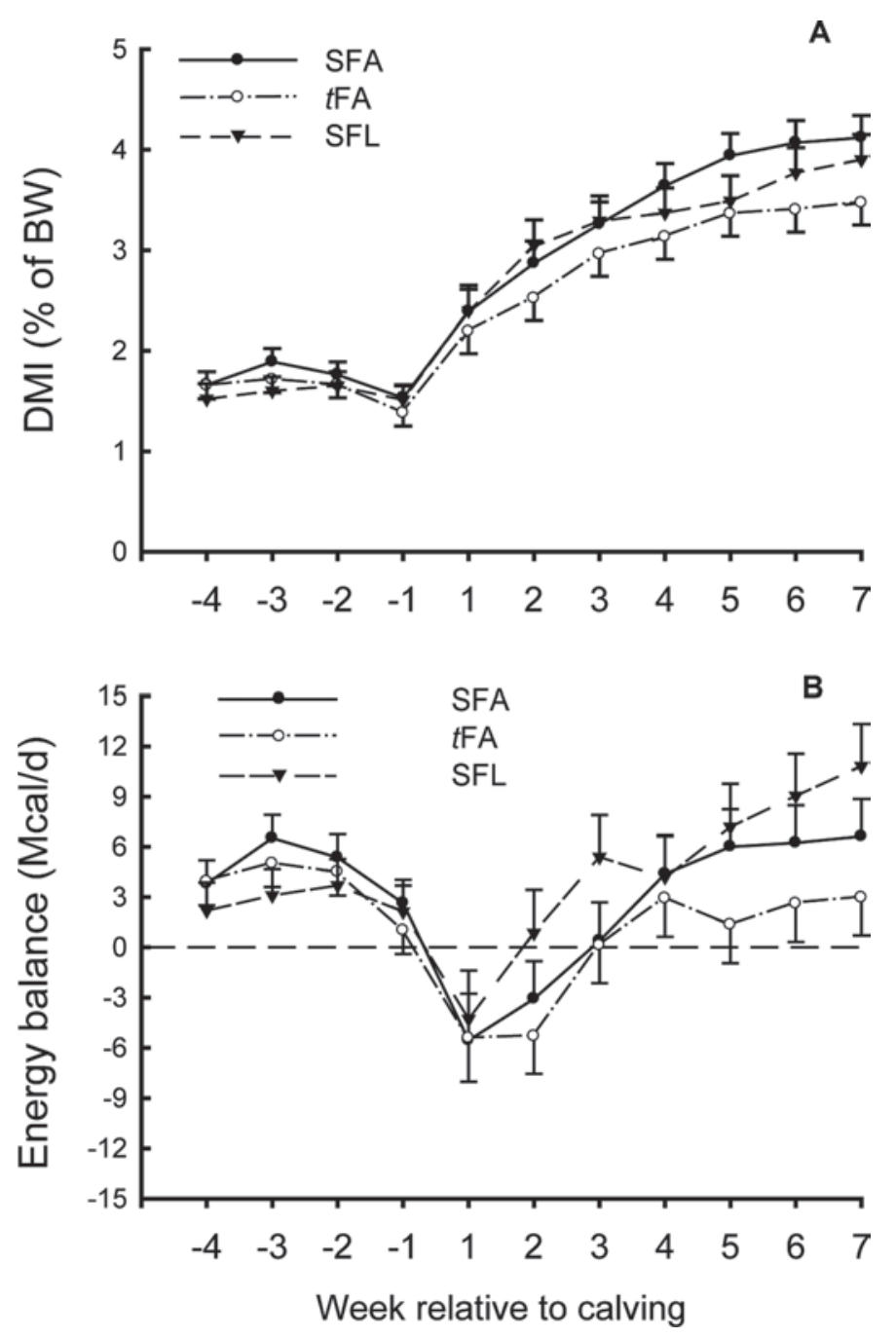

Figure 1. Dry matter intakes (A) and calculated energy balances (B) of periparturient Holstein cows fed diets containing fat supplements enriched in either saturated fatty acids (SFA, $n=10$ ), Ca salts of trans-octadecenoic fatty acids $(t \mathrm{FA}, \mathrm{n}=10)$, or Ca salts of safflower oil (SFL, $\mathrm{n}=9$ ) fatty acids. to first ovulation was $33.1 \pm 2.7$; Figure $4 \mathrm{~A}$ ), accumulated plasma progesterone increased faster and reached a greater concentration (diet $\times$ day interaction; $P<$ 0.01 ) by d 49 of lactation in Holstein cows fed the SFL supplement compared with cows fed the $t \mathrm{FA}$ or SFA supplements (Figure 4B).

\section{DISCUSSION}

Changes in metabolism of nutrients that are required to support lactation in high-producing dairy cows are regulated by metabolic hormones that coordinate several processes including FA mobilization from adipose tissue and glucose synthesis from gluconeogenic precursors in the liver (Radcliff et al., 2003; Overton and Waldron, 2004). This study used 29 multiparous Holstein cows to examine the effect of feeding 3 sources of fat on performance, metabolic and endocrine responses during the transition period. Pre- and postpartum BW and BCS were unaffected by feeding fat supplements differing in FA profile, indicating that BW and BCS changes may not be correlated closely with metabolic and endocrine changes associated with parturition in cattle (Thomas et al., 1997; Andersen et al., 2004). Postpartum negative energy balance (NEB) was more severe in cows fed the $t$ FA supplement than those fed the SFL supplement. This was likely a result of a combination of decreased DMI and increased production of 3.5\% FCM in cows fed $t$ FA compared with cows fed SFL. Results are consistent with previous studies that reported a considerable decrease in DMI by postpartum cows infused or supplemented with $t$ FA (Romo et al., 2000; Selberg et al., 2004). The mechanisms by which specific dietary FA alter DMI are complex. The FA profile of the fat supplement appears to play an important role in the control of feed intake. Dairy cows fed Ca salts of palm oil or of soybean oil tended $(P=0.12)$ to eat 
Table 6. Milk fatty acid composition ( $\mathrm{g}$ of fatty acids/100 g) of Holstein cows fed diets containing fat supplements enriched in either saturated fatty acids (SFA), Ca salts of trans-octadecenoic fatty acids $(t \mathrm{FA})$, or Ca salts of safflower oil (SFL) fatty acids ${ }^{1}$

\begin{tabular}{|c|c|c|c|c|c|c|}
\hline \multirow[b]{2}{*}{ Fatty acid } & \multicolumn{3}{|c|}{ Diet } & \multirow[b]{2}{*}{ SEM } & \multicolumn{2}{|c|}{$P$-value ${ }^{2}$} \\
\hline & SFA & $t \mathrm{FA}$ & SFL & & $\mathrm{C} 1$ & $\mathrm{C} 2$ \\
\hline $\mathrm{C} 4: 0$ & $3.71^{\mathrm{ab}}$ & $3.82^{\mathrm{a}}$ & $3.31^{\mathrm{b}}$ & 0.17 & 0.48 & 0.05 \\
\hline $\mathrm{C} 6: 0$ & $2.10^{\mathrm{a}}$ & $1.96^{\mathrm{a}}$ & $1.45^{\mathrm{b}}$ & 0.17 & $<0.01$ & $<0.01$ \\
\hline $\mathrm{C} 8: 0$ & $1.09^{\mathrm{a}}$ & $0.98^{\mathrm{a}}$ & $0.67^{\mathrm{b}}$ & 0.08 & $<0.01$ & 0.01 \\
\hline $\mathrm{C} 10: 0$ & $2.18^{\mathrm{a}}$ & $1.94^{\mathrm{b}}$ & $1.41^{\mathrm{b}}$ & 0.2 & 0.04 & 0.08 \\
\hline $\mathrm{C} 12: 0$ & 2.25 & 2.09 & 1.76 & 0.2 & 0.18 & 0.25 \\
\hline C14:0 & 7.92 & 7.46 & 7.58 & 0.56 & 0.55 & 0.89 \\
\hline $\mathrm{C} 14: 1$ cis-9 & 0.53 & 0.52 & 0.67 & 0.06 & 0.42 & 0.13 \\
\hline C16:0 & $26.2^{\mathrm{a}}$ & $22.98^{\mathrm{b}}$ & $24.68^{\mathrm{ab}}$ & 0.81 & 0.02 & 0.17 \\
\hline C16:1 cis-9 & 1.34 & 1.28 & 1.49 & 0.1 & 0.69 & 0.15 \\
\hline $\mathrm{C} 18: 0$ & $11.88^{\mathrm{a}}$ & $10.71^{\mathrm{a}}$ & $7.89^{\mathrm{b}}$ & 0.45 & $<0.01$ & $<0.01$ \\
\hline$\Sigma 18: 1$ trans & $4.44^{\mathrm{a}}$ & $8.71^{\mathrm{b}}$ & $14.34^{\mathrm{c}}$ & 0.81 & $<0.01$ & $<0.01$ \\
\hline $\mathrm{C} 18: 1$ trans -4 & $0.02^{\mathrm{a}}$ & $0.03^{\mathrm{b}}$ & $0.04^{\mathrm{b}}$ & 0 & $<0.01$ & 0.73 \\
\hline $\mathrm{C} 18: 1$ trans -5 & $0.01^{\mathrm{a}}$ & $0.04^{\mathrm{b}}$ & $0.04^{\mathrm{b}}$ & 0 & $<0.01$ & 0.97 \\
\hline C18:1 trans- $6-8$ & $0.36^{\mathrm{a}}$ & $0.99^{\mathrm{b}}$ & $0.78^{\mathrm{c}}$ & 0.06 & $<0.01$ & 0.02 \\
\hline C18:1 trans -9 & $0.30^{\mathrm{a}}$ & $0.88^{\mathrm{b}}$ & $0.62^{\mathrm{c}}$ & 0.05 & $<0.01$ & $<0.01$ \\
\hline $\mathrm{C} 18: 1$ trans -10 & $1.09^{\mathrm{a}}$ & $1.49^{\mathrm{a}}$ & $5.24^{\mathrm{b}}$ & 0.73 & 0.01 & $<0.01$ \\
\hline $\mathrm{C} 18: 1$ trans -11 & $1.22^{\mathrm{a}}$ & $2.40^{\mathrm{a}}$ & $4.99^{\mathrm{b}}$ & 0.46 & $<0.01$ & $<0.01$ \\
\hline C18:1 trans- 12 & $0.47^{\mathrm{a}}$ & $1.10^{\mathrm{b}}$ & $1.01^{\mathrm{b}}$ & 0.06 & $<0.01$ & 0.3 \\
\hline $\mathrm{C} 18: 1$ cis-9 & $25.05^{\mathrm{a}}$ & $25.00^{\mathrm{a}}$ & $19.50^{\mathrm{b}}$ & 1.59 & 0.15 & 0.03 \\
\hline $\mathrm{C} 18: 2$ cis $(\mathrm{n}-6)$ & $3.09^{\mathrm{a}}$ & $3.30^{\mathrm{a}}$ & $3.77^{\mathrm{b}}$ & 0.15 & 0.02 & 0.04 \\
\hline $\mathrm{C} 20: 0$ & 0.12 & 0.11 & 0.13 & 0.01 & 0.83 & 0.09 \\
\hline $\mathrm{C} 18: 3$ cis $(\mathrm{n}-3)$ & $0.31^{\mathrm{a}}$ & $0.32^{\mathrm{a}}$ & $0.41^{\mathrm{b}}$ & 0.02 & $<0.01$ & $<0.01$ \\
\hline CLA $^{3}$ cis -9, trans -11 & $0.45^{\mathrm{a}}$ & $0.91^{\mathrm{b}}$ & $1.67^{\mathrm{c}}$ & 0.13 & $<0.01$ & $<0.01$ \\
\hline CLA trans-10, cis-12 & n.d. ${ }^{\mathrm{a}}$ & n.d. ${ }^{\mathrm{a}}$ & $0.03^{\mathrm{b}}$ & 0.005 & $<0.01$ & $<0.01$ \\
\hline Other & $0.64^{\mathrm{a}}$ & $0.67^{\mathrm{a}}$ & $0.96^{\mathrm{b}}$ & 0.04 & $<0.01$ & $<0.01$ \\
\hline$\Sigma \mathrm{n}-6^{4}$ & $3.42^{\mathrm{a}}$ & $3.60^{\mathrm{a}}$ & $4.01^{\mathrm{b}}$ & 0.15 & 0.05 & 0.08 \\
\hline$\Sigma \mathrm{n}-3^{5}$ & $0.38^{\mathrm{a}}$ & $0.41^{\mathrm{a}}$ & $0.65^{\mathrm{b}}$ & 0.02 & $<0.01$ & $<0.01$ \\
\hline & $9.09^{\mathrm{a}}$ & $8.79^{\mathrm{a}}$ & $6.18^{\mathrm{b}}$ & 0.3 & $<0.01$ & $<0.01$ \\
\hline \multicolumn{7}{|l|}{ Summation by origin ${ }^{6}$} \\
\hline$<16 \mathrm{C}$ & 21.44 & 20.28 & 18.43 & 1.22 & 0.17 & 0.31 \\
\hline $16 \mathrm{C}$ & $28.46^{\mathrm{a}}$ & $25.25^{\mathrm{b}}$ & $27.61^{\mathrm{a}}$ & 0.8 & 0.04 & 0.05 \\
\hline$>16 \mathrm{C}$ & 47.79 & 51.7 & 47 & 1.77 & 0.47 & 0.08 \\
\hline
\end{tabular}

${ }^{\mathrm{a}-\mathrm{c}}$ Within the same row, means with different superscripts are statistically different, as determined by piecewise differentiable (PDIFF) category.

${ }^{1}$ Values represent an average of wk 6 and 7 of lactation.

${ }^{2}$ Contrasts: $\mathrm{C} 1=\mathrm{SFA}$ vs. $t \mathrm{FA}+\mathrm{SFL} ; \mathrm{C} 2=t \mathrm{FA}$ vs. SFL.

${ }^{3}$ Conjugated linoleic acid.

${ }^{4}$ Sum of n-6 FA: C18:2+C18:3+C20:2+C20:3+C20:4+C22:4.

${ }^{5} \mathrm{Sum}$ of n-3 FA: C18:3+C20:3+C20:5+C22:5+C22:6.

${ }^{6} \mathrm{FA}<\mathrm{C} 16$ originate from de novo synthesis; C16:0 + 16:1 FA come from de novo and preformed sources; and FA $>$ C16 are preformed fatty acids taken up by the mammary gland.

less DM than did cows fed a saturated FA supplement (Relling and Reynolds, 2007). These decreased intakes were accompanied by increased plasma concentrations of glucagon-like peptide-1 and cholecystokinin. Cows fed the monounsaturated FA (palm oil) had greater plasma concentrations of cholecystokinin than cows fed the polyunsaturated FA. If the monounsaturated FA in $t \mathrm{FA}$ affected cholecystokinine to a greater degree than did SFA and SFL in the current study, DMI would be expected to be decreased.

Multiparous Holstein cows fed the SFL-enriched diet were in a more positive energy balance after calving than cows fed the $t \mathrm{FA}$-enriched diet. It is likely that the improved energy status of SFL-supplemented cows detected in this study was due largely to decreased energy output in the form of decreased production of FCM. Decreased milk energy output was due mainly to a dramatic decrease in milk fat concentration from 3.78 to $2.81 \%$ (SFA vs. SFL; Table 5). In fact, feeding the SFL supplement resulted in a $\mathrm{NE}_{\mathrm{L}}$ savings of 3.5 $\mathrm{Mcal} / \mathrm{d}$ compared with that of the $t \mathrm{FA}$ supplement. With less energy being exported by cows fed SFL, less energy would be needed to be mobilized from adipose tissue. Accompanying improved energy balance was a decrease in plasma concentration of NEFA for cows fed SFL vs. $t$ FA. Depression of milk fat synthesis by dietary safflower oil or seed has been reported previously (Bell et al., 2006; Dschaak et al., 2010). Existing data indi- 

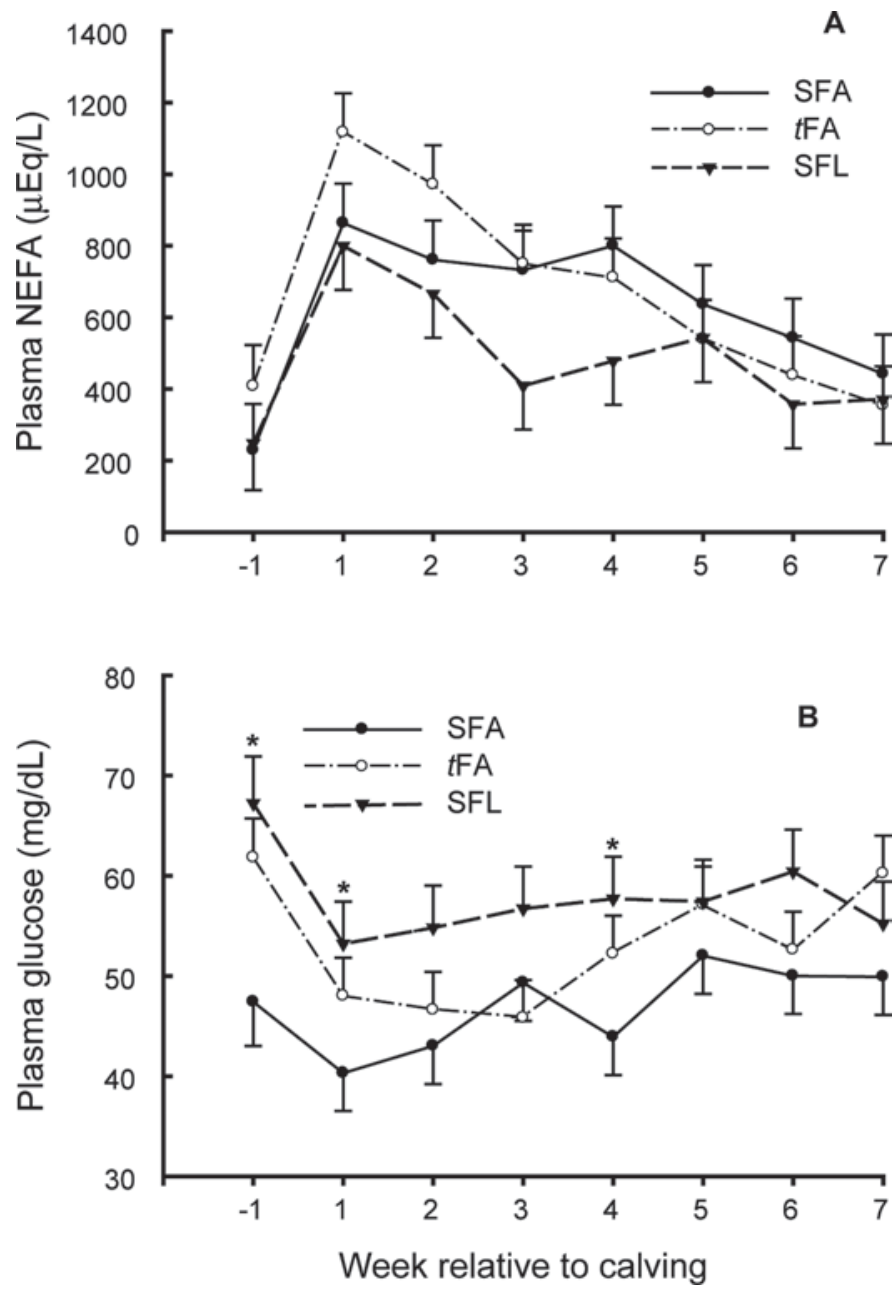

Figure 2. Plasma nonesterified fatty acids (A) and glucose (B) of periparturient Holstein cows fed diets containing fat supplements enriched in either saturated fatty acids $(\mathrm{SFA}, \mathrm{n}=10)$, Ca salts of trans-octadecenoic fatty acids $(t \mathrm{FA}, \mathrm{n}=9)$, or Ca salts of safflower oil $(\mathrm{SFL}, \mathrm{n}=8)$ fatty acids. Asterisks indicate significant differences $(P$ $<0.05)$ at corresponding week.

cate that, under certain dietary conditions, alterations in microbial biohydrogenation produce specific FA that are potent regulators of mammary synthesis of milk fat. To date, 3 specific intermediates from microbial biohydrogenation have been shown to cause milk fat depression (MFD) when infused as pure isomers postruminally in lactating dairy cows, with trans-10, cis-12 CLA the intermediate most studied and well characterized (Harvatine et al., 2009). Consistent with the effects of trans-10, cis-12 CLA on milk fat synthesis in the mammary gland, we observed a significant increase in the concentration of this FA as well as trans-10 18:1 in milk fat in SFL-treated cows, which would have contributed to the decrease in milk fat content and yield for this treatment group. Postpartum diets in the current study were borderline in fiber adequacy, averaging 16.9\%.
Dairy NRC (2001) recommends a minimum range between 18 to $21 \% \mathrm{ADF}$. It is likely that the ruminal $\mathrm{pH}$ of cows consuming these diets was more acidic than normal and would have helped create a scenario leading to increased formation of FA isomers linked to MFD.

Compared with SFA and $t \mathrm{FA}$ supplementation, the SFL treatment increased milk fat concentrations of trans-18:1 isomers. The most pronounced increases occurred in trans-10 and trans-11 18:1 isomers. Similar increases in milk fat trans 18:1 FA concentrations have been reported following $t$ FA (Piperova et al., 2004; Selberg et al., 2004), safflower oil (Bell et al., 2006; Dschaak et al., 2010), or PUFA (Griinari et al., 1998; Theurer et al., 2009) supplementation of dairy cow diets. Typically, unsaturated FA undergo partial biohydrogenation in the rumen, resulting in the production of several trans 18:1 intermediates. Because Ca salts of SFL used in the present study contained mostly linoleic acid, which is a primary substrate for microbial biohydrogenation, it is likely that the increased concentration of trans 18:1 isomers in milk fat from SFL-supplemented cows originated from incomplete biohydrogenation of linoleic acid in the rumen. Taken together, these findings would indicate that a substantial portion of the PUFA from Ca salts of SFL are dissociated in the rumen and undergo biohydrogenation.

Concentrations of CLA in milk fat were increased greatly by peripartum supplementation of Ca salts of $t$ FA (2.0-fold) and SFL (3.7-fold) compared with the SFA supplement. The diet-induced increases in milk fat CLA were more pronounced for cis-9, trans-11 CLA (3.7-fold) than for trans-10, cis-12 CLA. Results are in agreement with those of Bell et al. (2006) who reported that dairy cows fed safflower oil produced milk fat with 7.5 times more cis-9, trans-11 CLA than did cows fed the control diet. The relatively smaller increase of $c i s-9$, trans-11 CLA by supplemental SFL in our study compared with the increase reported by Bell et al. (2006), was likely due to different physical forms (i.e., safflower oil vs. Ca salts of safflower oil) of fat supplements in the 2 studies. Whereas some of the milk CLA originates from incomplete biohydrogenation of PUFA in the rumen, the majority of milk cis-9, trans-11 CLA is synthesized endogenously by mammary $\Delta^{9}$-desaturase (Lock et al., 2009). Consequently, the greater concentration of cis-9, trans-11 CLA detected in milk from SFLsupplemented cows may be a direct result of increased substrate (trans-11 18:1) availability for the mammary $\Delta^{9}$-desaturase enzyme. Indeed, the concentration of trans-11 C18:1 was doubled in milk fat from cows fed SFL compared with cows fed $t$ FA.

Plasma NEFA concentration was decreased, whereas circulating glucose concentration was increased by SFL supplementation to Holstein cows. In a previous study, 

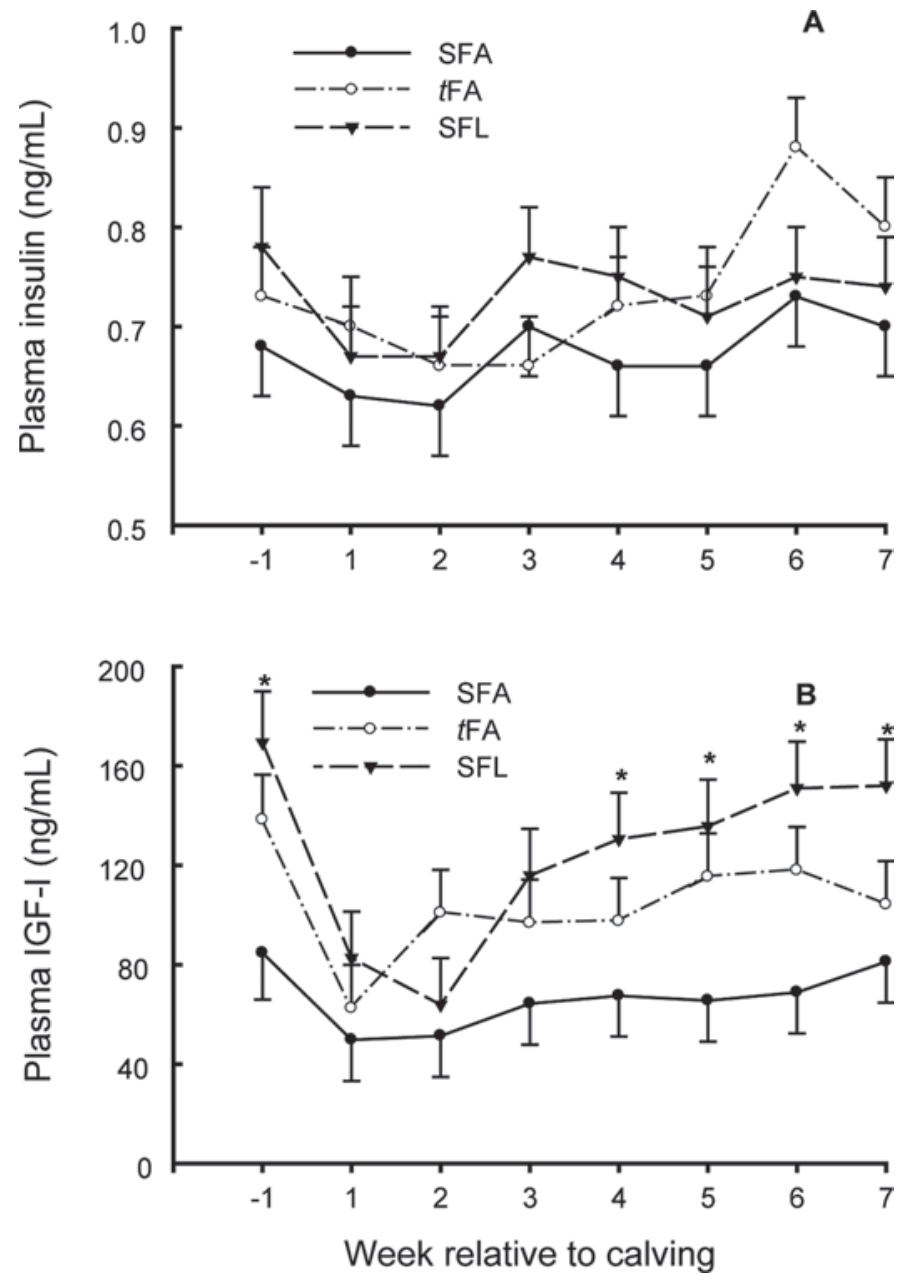

Figure 3. Plasma insulin (A) and IGF-I (B) of periparturient Holstein cows fed diets containing fat supplements enriched in either saturated fatty acids (SFA, $\mathrm{n}=10$ ), Ca salts of trans-octadecenoic fatty acids $(t \mathrm{FA}, \mathrm{n}=9)$, or Ca salts of safflower oil (SFL, $\mathrm{n}=8)$ fatty acids. Asterisks indicate significant differences $(P<0.05)$ at corresponding week.

intravenous infusion of an emulsion derived from linseed oil to feed-restricted nonlactating Holstein cows resulted in decreased plasma concentrations of NEFA and BHBA and tended to reduce liver triacylglycerol accumulation, compared with tallow (Mashek et al., 2005). Because FA oxidation did not differ between cows fed the fat supplements, the authors concluded that modifications in adipose tissue metabolism by linolenic acid originating from linseed oil might have enhanced adipose sensitivity to insulin and increased insulin-mediated inhibition of lipolysis (Mashek et al., 2005). Whether or not adipose and liver sensitivities to insulin are altered by dietary SFL has not been documented. Our findings are similar to those reported by Castañeda-Gutiérres et al. (2005) who showed doserelated decrease in milk fat by dietary supplements of
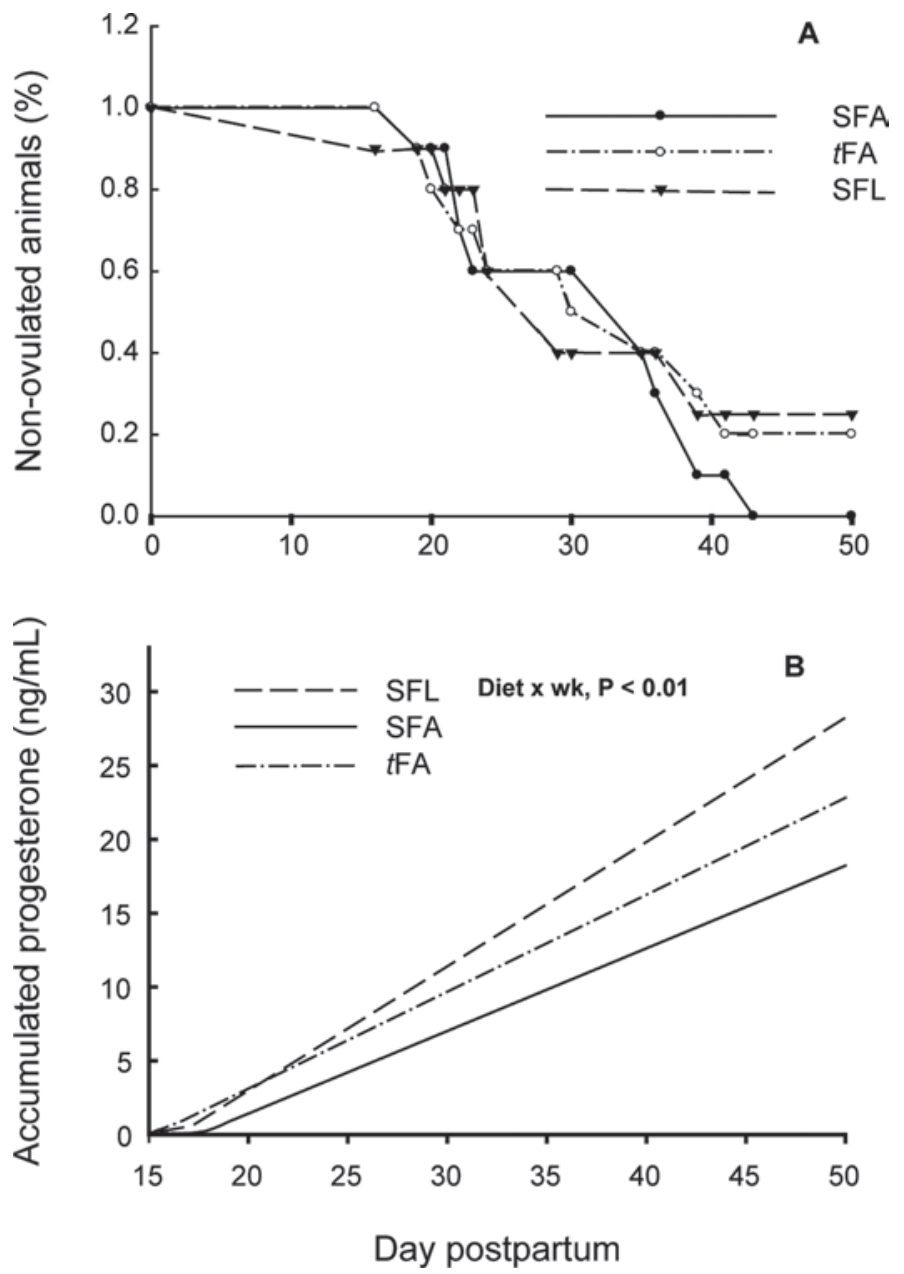

Figure 4. Ovulatory (A) and progesterone (B) responses of periparturient Holstein cows fed diets containing fat supplements enriched in either saturated fatty acids (SFA, $\mathrm{n}=10$ ), Ca salts of trans-octadecenoic fatty acids $(t \mathrm{FA}, \mathrm{n}=10$ ), or Ca salts of safflower oil (SFL, $\mathrm{n}$ $=9)$ fatty acids. A diet $\times$ day interaction was detected $(P<0.01)$ for postpartum accumulated progesterone concentration.

CLA during the transition period. At the higher dose, the CLA-induced MFD decreased milk energy output without a significant improvement in net energy balance or decrease in the use of body fat as evaluated by changes in BW or BCS. These observations collectively indicate that peripartum supplementation of CLA or linoleic acid may improve endocrine signals that can be beneficial to production. Further studies are needed to clarify the partitioning of energy in SFL-supplemented cows and to document whether or not the responses detected in this study were SFL-specific or resulted from MFD induced by peripartum SFL supplementation.

In high-producing dairy cows, plasma IGF-I concentration decreases at parturition and increases gradually as GH receptors are upregulated at the liver (Kobayashi et al., 1999; Radcliff et al., 2003). In the 
present study, peripheral IGF-I concentrations were consistently greater in periparturient Holstein cows supplemented with SFL compared with those consuming the SFA-enriched diet. Because insulin increases the abundance of $\mathrm{GH}$ receptor in cattle liver (Butler et al., 2003; Rhoads et al., 2004), it is conceivable that the SFL-stimulated IGF-I production was caused by numerically greater insulin concentration in cows fed a linoleic acid-enriched diet. Alternatively, the greater IGF-I in the SFL group could reflect the milder NEB in postpartum cows fed SFL compared with that in the other treatment groups. Further studies are needed to fully examine the relationship between dietary safflower oil and liver production of IGF-I in dairy cattle.

In lactating dairy cows, the NEB during the first 3 to $4 \mathrm{wk}$ after parturition is inversely related to the interval to first normal ovulation (Butler et al., 1981). In the present study, peripartum fat feeding had minimal effects on the number of days to first ovulation after parturition. However, accumulated progesterone and IGF-I concentrations at d 49 postpartum were greater in cows fed SFL than in those fed the SFA supplement. Results provide further evidence for the importance of IGF-I in the control of ovarian steroidogenesis, and would indicate that peripartum SFL supplementation may improve corpus luteum development and function in lactating dairy cows.

\section{CONCLUSIONS}

Results of this study provide further evidence that metabolism of the dairy cow can be modulated through dietary manipulation using long-chain FA. Inclusion of Ca salts of SFL in the peripartum diet decreased milk fat synthesis, which might have decreased the nutrient demands for milk synthesis, helping lactating cows establish a more positive energy balance sooner after parturition. Additionally, the observation that peripartum supplementation with SFL compared with SFA was associated with greater concentrations of glucose, IGF-I, and accumulated progesterone in blood, would indicate that peripartum supplementation of n- 6 FA may affect fertility responses of early lactation dairy cattle.

\section{ACKNOWLEDGMENTS}

The authors thank Virtus Nutrition (Fairlawn, $\mathrm{OH}$ ) and Cargill (Minneapolis, MN) for providing supplemental fats for this study. Appreciation is extended to Milerky Perdomo (University of Gainesville, FL) for helping with animal handling and blood sampling and to Courtney Preseault (Michigan State University, East Lansing, MI) for assistance with milk FA analysis.

\section{REFERENCES}

Amaral, B. C. D. 2008. Effect of supplemental fat source on production, immunity, hepatic gene expression, and metabolism of periparturient dairy cows. PhD Diss. University of Florida, Gainesville.

Andersen, J. B., N. C. Friggens, T. Larsen, M. Vestergaard, and K. L. Ingvarsten. 2004. Effect of energy density in the diet and milking frequency on plasma metabolites and hormones in early lactation dairy cows. J. Vet. Med. A Physiol. Pathol. Clin. Med. $51: 52-57$.

Bell, A. W. 1981. Lipid metabolism in liver and selected tissues and in the whole body of ruminant animals. Page 363-399 in Lipid Metabolism in Ruminant Animals. 1st ed. W. W. Christie, ed. Pergamon Press, Oxford, UK.

Bell, A. W. 1995. Regulation of organic nutrient metabolism during the transition from late pregnancy to early lactation. J. Anim. Sci. 73:2804-2819.

Bell, A. W., and D. E. Bauman. 1997. Adaptations of glucose metabolism during pregnancy and lactation. J. Mammary Gland Biol. Neoplasia 2:265-278.

Bell, J. A., J. M. Griinari, and J. J. Kennelly. 2006. Effect of safflower oil, flaxseed oil, monensin, and vitamin E on concentration of conjugated linoleic acid in bovine milk fat. J. Dairy Sci. 89:733-748.

Bichell, D. P., K. Kikuchi, and P. Rotwein. 1992. Growth hormone rapidly activates insulin-like growth factor I gene transcription in vivo. Mol. Endocrinol. 6:1899-1908.

Bilby, T. R., A. Sozzi, M. M. Lopez, F. T. Silvestre, A. D. Ealy, C. R. Staples, and W. W. Thatcher. 2006. Pregnancy, bovine somatotropin, and dietary n-3 fatty acids in lactating dairy cows: I. Ovarian, conceptus, and growth hormone-insulin-like growth factor system responses. J. Dairy Sci. 89:3360-3374.

Butler, S. T., A. L. Marr, S. H. Pelton, R. P. Radcliff, M. C. Lucy, and W. R. Butler. 2003. Insulin restores GH responsiveness during lactation-induced negative energy balance in dairy cattle: Effects on expression of IGF-I and GH receptor 1A. J. Endocrinol. 176:205-217.

Butler, W. R., R. W. Everett, and C. E. Coppock. 1981. The relationships between energy balance, milk production and ovulation in postpartum Holstein cows. J. Anim. Sci. 53:742-748.

Castañeda-Gutiérres, E., T. R. Overton, W. R. Butler, and D. E Bauman. 2005. Dietary supplements of two doses of calcium salts of conjugated linoleic acid during the transition period and early lactation. J. Dairy Sci. 88:1078-1089.

Christie, W. W. 1989. Gas Chromatography and Lipids: A Practical Guide. The Oily Press, Ayr, Scotland.

Cullens, F. M., C. R. Staples, T. R. Bilby, F. Silvestre, J. Bartolome, A. Sozzi, L. Badinga, W. W. Thatcher, and J. D. Arthington. 2004. Effect of timing of initiation of fat supplementation on milk production, plasma hormones and metabolites, and conception rates of Holstein cows in summer. J. Dairy Sci. 87(Suppl. 1):308. (Abstr.)

Doepel, L., H. Lapierre, and J. J. Kennelly. 2002. Peripartum performance and metabolism of dairy cows in response to prepartum energy and protein intake. J. Dairy Sci. 85:2315-2334.

Douglas, G. N., T. R. Overton, H. G. Bateman II, H. M. Dann, and J. K. Drackley. 2006. Prepartal plane of nutrition, regardless of dietary energy source, affects periparturient metabolism and dry matter intake in Holstein cows. J. Dairy Sci. 89:2141-2157.

Douglas, G. N., T. R. Overton, H. G. Bateman II, and J. K. Drackley. 2004. Peripartal metabolism and production of Holstein cows fed diets supplemented with fat during the dry period. J. Dairy Sci. $87: 4210-4220$.

Drackley, J. K. 1999. Biology of dairy cows during the transition period: The final frontier? J. Dairy Sci. 82:2259-2273.

Dschaak, C. M., J.-S. Eun, A. J. Young, and J. W. Bergman. 2010. Nutritive merits of whole Nutrasaff safflower seed when fed to Holstein dairy cows during midlactation. Anim. Feed Sci. Technol. 156:26-36.

Etherton, T. D., and D. E. Bauman. 1998. Biology of somatotropin in growth and lactation of domestic animals. Physiol. Rev. 78:745761 
Fenwick, M. A., R. Fitzpatrick, D. A. Kenny, M. G. Diskin, J. Patton, J. J. Murphy, and D. C. Wathes. 2008. Interrelationships between negative energy balance (NEB) and IGF regulation in liver of lactating dairy cows. Domest. Anim. Endocrinol. 34:31-44.

Griinari, J. M., D. A. Dwyer, M. A. McGuire, D. E. Bauman, D. L. Palmquist, and K. V. V. Nurmela. 1998. Trans-octadecenoic acids and milk fat depression in lactating dairy cows. J. Dairy Sci. 81:1251-1261.

Grum, D. E., J. K. Drackley, R. S. Younker, D. W. LaCount, and J. J. Veenhuizen. 1996. Nutrition during the dry period and hepatic lipid metabolism of periparturient dairy cows. J. Dairy Sci. 79:1850-1864.

Grummer, R. R., and D. J. Carroll. 1991. Effects of dietary fat on metabolic disorders and reproductive performance of dairy cattle. J. Anim. Sci. 69:3838-3852.

Hara, A., and N. S. Radin. 1978. Lipid extraction of tissues with a low-toxicity solvent. Anal. Biochem. 90:420-426.

Harvatine, K. J., Y. R. Boisclair, and D. E. Bauman. 2009. Recent advances in the regulation of milk fat synthesis. Animal 3:40-54.

Herdt, T. H. 1988. Fatty liver in dairy cows. Vet. Clin. North Am. Food Anim. Pract. 4:269-287.

Kobayashi, Y., C. K. Boyd, C. J. Bracken, W. R. Lamberson, D. H Keisler, and M. C. Lucy. 1999. Reduced growth hormone receptor (GHR) messenger ribonucleic acid in liver of periparturient cattle is caused by a specific down-regulation of GHR 1A that is associated with decreased insulin-like growth factor I. Endocrinology 140:3947-3954.

Kramer, J. K. G., C. Cruz-Hernandez, and J. Q. Zhou. 2001. Conjugated linoleic acids and octadecenoic acids: Analysis by GC. Eur. J. Lipid Sci. Technol. 103:600-609.

Le Roith, D., C. Bondy, S. Yakar, J.-L. Liu, and A. Butler. 2001. The somatomedin hypothesis: 2001. Endocr. Rev. 22:53-74.

Lock, A. L., J. Kraft, B. H. Rice, and D. E. Bauman. 2009. Biosynthesis and biological activity of rumenic acid: A natural CLA isomer. Pages 195-230 in Trans Fatty Acid in Human Nutrition. 2nd ed. F. Destaillats, J.-L. Sébédio, F. Dionisi, and J.-M. Chardigny, ed. The Oily Press, Bridgewater, UK.

Mashek, D. G., S. J. Bertics, and R. R. Grummer. 2005. Effects of intravenous triacylglycerol emulsions on hepatic metabolism and blood metabolites in fasted dairy cows. J. Dairy Sci. 88:100109 .

NRC. 2001. Nutrient Requirements of Dairy Cattle. 7th rev. ed. Natl. Acad. Sci., Washington, DC.

Overton, T. R., and M. R. Waldron. 2004. Nutritional management of transition dairy cows: Strategies to optimize metabolic health. J. Dairy Sci. 87(E. Suppl.):E105-E119.

Piperova, L. S., U. Moallem, B. B. Teter, J. Sampugna, M. P. Yurawecz, K. M. Morehouse, D. Luchini, and R. A. Erdman. 2004. Changes in milk fat in response to dietary supplementation with calcium salts of trans-18:1 or conjugated linoleic fatty acids in lactating dairy cows. J. Dairy Sci. 87:3836-3844.
Radcliff, R. P., B. L. McCormack, B. A. Crooker, and M. C. Lucy. 2003. Plasma hormones and expression of growth hormone receptor and insulin-like growth factor-I mRNA in hepatic tissue of periparturient dairy cows. J. Dairy Sci. 86:3920-3926.

Relling, A. E., and C. K. Reynolds. 2007. Feeding rumen-inert fats differing in their degree of saturation decreases intake and increases plasma concentrations of gut peptides in lactating dairy cows. J. Dairy Sci. 90:1506-1515.

Rhoads, R. P., J. W. Kim, B. L. Leury, L. H. Baumgard, N. Segoale, S. J. Frank, D. E. Bauman, and Y. R. Boisclair. 2004. Insulin increases the abundance of the growth hormone receptor in liver and adipose tissue of periparturient dairy cows. J. Nutr. 134:1020-1027.

Romo, G. A., R. A. Erdman, B. B. Teter, J. Sampugna, and D. P. Casper. 2000. Milk composition and apparent digestibilities of dietary fatty acids in lactating dairy cows abomasally infused with Cis and Trans fatty acids. J. Dairy Sci. 83:2609-2619.

Selberg, K. T., A. C. Lowe, C. R. Staples, N. D. Luchini, and L. Badinga. 2004. Production and metabolic responses of periparturient Holstein cows to dietary conjugated linoleic acid and trans-octadecenoic acids. J. Dairy Sci. 87:158-168.

Selberg, K. T., C. R. Staples, N. D. Luchini, and L. Badinga. 2005. Dietary trans octadecenoic acids upregulate the liver gene encoding peroxisome proliferator- $\alpha$ in transition dairy cows. J. Dairy Res. 72:107-114.

Sharma, B. K., M. J. Vandehaar, and N. K. Ames. 1994. Expression of insulin-like growth factor-I in cows at different stages of lactation and late lactation cows treated with somatotropin. J. Dairy Sci. $77: 2232-2241$

Taylor, V. J., Z. Cheng, P. G. A. Pushpakumara, D. E. Beever, and D. C. Wathes. 2004. Relationships between the plasma concentrations of insulin-like growth factor-I in dairy cows and their fertility and milk yield. Vet. Rec. 155:583-588.

Theurer, M. L., E. Block, W. K. Sanchez, and M. A. McGuire. 2009. Calcium salts of polyunsaturated fatty acids deliver more essential fatty acids to the lactating dairy cow. J. Dairy Sci. 92:20512056.

Thissen, J. P., J. M. Ketelslegers, and L. E. Underwood. 1994. Nutritional regulation of the insulin-like growth factors. Endocr. Rev. 15:80-101.

Thomas, M. G., B. Bao, and G. L. Williams. 1997. Dietary fats varying in their fatty acid composition differentially influence follicular growth in cows fed isoenergetic diets. J. Anim. Sci. 75:25122519.

Ulberth, F., and F. Schrammel. 1995. Accurate quantitation of shortchain, medium-chain, and long-chain fatty acid methyl-esters by split-injection capillary gas-chromatography. J. Chromatogr. A 704:455-463.

Vandehaar, M. J., B. K. Sharma, and R. L. Fogwell. 1995. Effect of dietary energy restriction on the expression of insulin-like growth factor-I in liver and corpus luteum of heifers. J. Dairy Sci. 78:832-841. 